\title{
The effect of monetary unification on public debt and its real return
}

\author{
Roel M.W.J. Beetsma • Koen Vermeylen
}

Received: 11 September 2006 / Accepted: 4 June 2007 / Published online: 13 July 2007

(C) Springer Science+Business Media, BV 2007

\begin{abstract}
We explore the implications of monetary unification for real interest rates and (relative) public debt levels. The adoption of a common monetary policy renders the riskreturn characteristics of the participating countries' public debt more similar. The implied reduction in the scope for risk diversification raises the average expected real return on the debt. Also, the share of the union-wide debt issued by relatively myopic governments or of countries that initially have a relatively dependent central bank increases after unification. This may put the political sustainability of the union under pressure. A transfer scheme that penalizes debt increases beyond the union average is able to undo the interest rate effect of unification, but magnifies the spread in relative debt levels.
\end{abstract}

Keywords Monetary union - (Relative) Public debt · Interest rates · Externalities · Substitutability · Central bank independence

JEL Classification E42 $\cdot$ E62 $\cdot$ E63 $\cdot$ F33

\section{Introduction}

The implications of European Monetary Union (EMU) for public debt and, in particular, the real returns on public debt, have so far received only rather limited attention. ${ }^{1}$ Many

\footnotetext{
${ }^{1}$ Van Aarle et al. (1997), Beetsma and Bovenberg (1999) and Illing (1999) study the implications of monetary unification for public debt, while Beetsma and Uhlig (1999) and Leith and Wren-Lewis (2000, 2002) investigate public debt in a monetary union when fiscal rules are present. Missale (1999) provides an extensive discussion of public debt policies in Europe before EMU. Canzoneri and Diba (1991) and Restoy (1996) analyze real interest rates in a monetary union, while Chang (1990) explores the international externalities of national fiscal policies for the real interest rate. De Grauwe and Polan (2001) provide an informal discussion
}

R.M.W.J. Beetsma ( $₫)$

University of Amsterdam, CEPR and CESifo, Amsterdam, The Netherlands

e-mail: R.M.W.J.Beetsma@uva.nl

K. Vermeylen

University of Amsterdam, Amsterdam, The Netherlands

e-mail: K.Vermeylen@uva.nl 
economists believe that, even if there are any such implications, these are mainly the concern of individual EMU participants, because the spillover effects of any policy changes induced by EMU are uncertain and small (e.g., Buiter et al. 1993). In particular, as many would argue, to the extent that an individual increase in public debt leads to higher debt-servicing costs, these additional costs are borne only by the country under consideration in the form of a higher risk premium in the debt return.

In this paper we demonstrate that this view may not be correct. For this purpose, we build a simple theoretical model that can be used to analyze the implications of monetary unification for public debt and its costs. The model is purposefully kept as simple as possible, but has one major novel feature: as we want to analyze the effect of monetary unification on the supply of the public debt, we do not only model the demand side of the bond market (as is the case in most of the literature), but also its supply side. Monetary unification increases the correlation of the real returns on the public debt of the member countries by reducing idiosyncratic shocks to national inflation rates. ${ }^{2}$ The enhanced substitutability of the various member countries' public debt in the portfolios of the investors reduces the attractiveness to the latter of holding this debt. As a result, the expected real interest rate paid on the debt exceeds its pre-unification level. Such a potential increase in debt-servicing costs has also been recognized by the European Commission (2002, p. 156).

Because of indirect effects running via the consumption pattern, the general equilibrium implications for the debt level are ambiguous. However, we find that the share of the union area's debt issued by countries with relatively undisciplined governments or relatively dependent central banks before unification increases after unification. We believe that this is an important implication of the model, because relative debt levels seem politically more relevant than absolute debt levels, as it is hard for a government to blame other governments for their fiscal laxity when its own debt is high. Because relative debt levels determine the relative importance of the interest rate externalities that countries exert on each other, they may become a source of tension in a monetary union. Indeed, in our model, a debt increase in one country exerts a direct positive effect on the required rate of return on other countries' debt when these countries all form a monetary union, while this effect is absent when the countries do not form a union. Hence, monetary unification may cause worries in low-debt countries about the fiscal discipline of highly-indebted countries. This may put pressure on the political sustainability of the monetary union. A fiscal transfer scheme conditional on public debt forces individual governments to internalize the interest rate externalities of their own debt policies. We show that such a scheme restores the before-unification average real borrowing cost. However, the scheme magnifies the spread in relative debt levels.

We emphasize that our analysis is positive and designed to highlight the mechanisms that may lead to the results described above. Hence, we refrain from analyzing the welfare consequences of monetary unification or of adopting a fiscal transfer scheme. That would require a more complicated modelling setup, which is beyond the scope of this paper.

The remainder of this paper is structured as follows. Section 2 presents the model. This section also derives the outcomes of the model under national monetary policymaking and a monetary union. Section 3 discusses the main results. Section 4 explores a simple transfer

of a.o. the implications of EMU for interest rate spillovers. Finally, for empirical work on the relation between public debt and real interest rates, see e.g. Ford and Laxton (1999).

${ }^{2}$ Evidence of reductions in yield spreads and increased bond return correlations in Europe after monetary unification can be found in Capiello et al. (2003), Baele et al. (2004) and Pagano and von Thadden (2004). 
scheme that induces governments to internalize the interest rate externalities caused by their debt policies. Finally, Sect. 5 concludes the paper with a discussion of the political institutions and processes underlying the government myopia that drives the debt and interest effects of monetary unification that, in turn, may help to determine the desire of re-election minded politicians to join a monetary union. In this section we also discuss other extensions of the present analysis.

\section{The model}

\subsection{Set-up}

We consider a world with $N>1$ countries. The countries $1, \ldots, N^{\mathrm{u}}$, with $2 \leq N^{\mathrm{u}} \leq N$, may form a monetary union, and we will compare the situation before and after monetary unification. The monetary union and its size are exogenous. In other words, we do not study the incentives for countries to participate in a monetary union. ${ }^{3}$ This enables us to focus on the issues at hand, namely the implications of monetary unification for public borrowing costs and relative debt levels. Moreover, in reality, monetary unification is often as much a political project as it is a project based on purely economic arguments. It is often argued that this is also the case for EMU.

The demographic structure consists of overlapping generations of a constant size. The countries are of equal size, with the size of a generation in a country normalized to 1 . Each generation lives for two periods and is represented by a representative agent per country. We adopt this simple overlapping generations structure, because it allows for a straightforward derivation of a simple demand function for public debt by private agents, thereby also allowing for explicit solutions of the model (see below).

In the sequel of this subsection, we describe the behavior of the representative agents, the governments and the central banks in the different countries. In the next subsection, we will solve the model and consider separately the case before and after monetary unification.

\subsubsection{The representative agents}

Consider the representative agent born in country $i$ in period $t$. In the first period of her life, she receives an exogenous endowment $Y$, pays taxes $T_{i, t}$, consumes part of her aftertax endowment, and saves the remainder for the second period of her life. In the second period of her life, she is retired and consumes her gross savings. The agent can save by holding public debt of each of the $N$ countries, or by investing in a production technology that yields an exogenously determined risk-free real rate of return $r^{*} \geq 0 .{ }^{4}$ Therefore, her

\footnotetext{
${ }^{3}$ The factors that determine the desirability of monetary unification were first explored by Mundell (1961). He emphasizes the role of transactions costs and labor mobility. Recent work has investigated the issue from a variety of other perspectives. For example, Neumeyer (1998) finds that the welfare effects of a monetary union depend on the trade-off between eliminating exchange rate fluctuations unrelated to economic shocks and reducing hedging possibilities (by reducing the number of currencies); Calmfors (2001) shows that unification alters the incentives for structural (labor market) reform; Beetsma and Bovenberg (1998) demonstrate that unification may change the strategic interactions among the fiscal and monetary policymakers in a beneficial way; and Cukierman and Lippi (2001) study the consequences of a monetary union for trade union behavior.

${ }^{4}$ Thus, an agent born in period $t$ foregoes consumption in that period by investing in this technology. However, for each unit invested in period $t$, she receives with certainty $1+r^{*}$ units back for consumption in period $t+1$.
} 
budget constraint is given by

$$
C_{2, t+1}^{i}=\left(Y-T_{i, t}-C_{1, t}^{i}\right)\left[\sum_{j=1}^{N} \omega_{j, t}^{i}\left(1+r_{j, t+1}\right)+\left(1-\sum_{j=1}^{N} \omega_{j, t}^{i}\right)\left(1+r^{*}\right)\right]
$$

where $C_{1, t}^{i}$ and $C_{2, t+1}^{i}$ are her consumption in periods $t$ and $t+1$, respectively, while $\omega_{j, t}^{i}$ is the share of her savings in period $t$ invested in public debt of country $j$ (such that $1-\sum_{j=1}^{N} \omega_{j, t}^{i}$ is the share of her savings invested in the risk-free technology) and $r_{j, t+1}$ is the (ex-post) real interest rate paid in period $t+1$ on the debt issued in period $t$. Below we derive the shares $\omega_{j, t}^{i}$ endogenously from the agent's optimization problem.

Subject to (1), the representative agent maximizes her expected lifetime utility:

$$
U_{t}^{i}=C_{1, t}^{i}-\frac{1}{2} \gamma\left(C_{1, t}^{i}\right)^{2}+\frac{1}{1+\rho} \mathrm{E}_{t}\left[C_{2, t+1}^{i}-\frac{1}{2} \gamma\left(C_{2, t+1}^{i}\right)^{2}\right], \quad \text { with } \gamma>0,
$$

where $\rho$ is the agent's discount rate and $\mathrm{E}_{t}[\cdot]$ is the expectations operator conditional on the available information in period $t$ (see below). In what follows, we will assume for simplicity that the risk-free interest rate $r^{*}$ is equal to the discount rate $\rho$. We also assume that $\gamma$ is such that the marginal utility of consumption is always positive in the situations that are relevant for the ensuing analysis.

\subsubsection{The governments}

Each country $i$ has a government, called "government $i$." The focus of the model is on the government's supply of public debt. Hence, the only role of government $i$ in each period $t$ is to decide how to finance an exogenous amount of spending $G_{i, t}$ (which does not affect private agents' utility or production possibilities), ${ }^{5}$ by raising $T_{i, t}$ and issuing public debt $B_{i, t}$. Taxes $T_{i, t}$ are lump-sum and have to be paid by the young generation in period $t$. Public debt has a maturity of one period, and therefore has to be paid back by the government (with interest) in period $t+1$. Hence, its dynamic budget constraint for period $t$ can be written as:

$$
B_{i, t}=G_{i, t}+B_{i, t-1}\left(1+r_{i, t}\right)-T_{i, t}
$$

where $B_{i, t-1}$ is the debt carried over from period $t-1$, which has to be paid off in period $t$. Public debt is issued at a nominal interest rate, such that the ex-post real interest rate $r_{i, t}$ equals this nominal interest rate minus the realized inflation rate.

Subject to (3), the government has to make a trade-off in period $t$ between higher taxes or issuing more public debt. On the one hand, higher taxes in period $t$ lower the lifetime utility of the generation that has to pay the taxes in that period. On the other hand, higher public debt leads to higher taxes in the future, and lowers the lifetime utility of the generations that have to pay taxes then. The resulting trade-off between the interests of the various generations can be captured with the following simple loss function for government $i$ in period $t$ :

$$
L_{i, t}^{\mathrm{gov}}=T_{i, t}+\frac{1}{1+\beta_{i}} \mathrm{E}_{t}\left[B_{i, t}\left(1+r_{i, t+1}\right)\right], \quad \text { with } \beta_{i}>0 .
$$

\footnotetext{
${ }^{5}$ Because government spending is exogenous we could have included it as a separate component in the individuals' utility without any consequences for the outcomes.
} 
While this loss function is not microfounded, the trade-off that it embodies is an important aspect of the policy decisions made in reality. ${ }^{6}$ Parameter $\beta_{i}$ captures the relative importance that government $i$ attaches to the interests of the current tax payers. Hence, we refer to this parameter as the degree of myopia of this government. Government myopia may differ across countries. In reality, such differences will be related to political factors, such as political polarization and the government turnover rate. ${ }^{7}$ The expected future debt burden also includes the real interest that government $i$ has to pay at that time. As public debt is issued at a nominal interest rate, uncertainty about the inflation rate in country $i$ between periods $t$ and $t+1$ causes uncertainty about the ex-post real interest rate $r_{i, t+1}$ (see below). As a result, when viewed from period $t$, the real value of the debt burden in period $t+1$ is uncertain.

\subsubsection{The central banks}

Before monetary unification takes place, each country $i$ has its own central bank. In period $t$, the central bank determines the growth rate of the money supply from period $t$ to period $t+1$, which we denote by $m_{i, t+1}$. Money is held by the representative individual in order to make transactions. In reality, for modern economies such as those of the Euro-area, seigniorage as a fraction of GDP is very small. In order to focus our attention on the issues as stake, we ignore seigniorage. Alternatively, we could assume that the central bank hands the seigniorage directly back to private agents, in which case all budget constraints are unaltered and the model solution is exactly as described below.

The growth rate of the money supply determines the inflation rate, but the link between money growth and inflation is stochastic and given by

$$
\pi_{i, t+1}=m_{i, t+1}\left(1+\varepsilon_{i, t+1}\right)
$$

where $\pi_{i, t+1}$ is the inflation rate in country $i$ between periods $t$ and $t+1$, and $\varepsilon_{i, t+1}$ is a stochastic shock with mean zero, variance $\sigma^{2}$ and which is i.i.d. over time (at all lags) and across countries. There are many reasons why a central bank has imperfect control over the inflation rate. For instance, there may be velocity shocks or the link between the base money supply and higher aggregation levels of the money supply (which are more closely linked to inflation) may be affected by unforeseen events in the commercial banking sector.

Because debt is issued at a nominal interest rate, using a standard linearization, the expost real interest rate on the debt is given by

$$
r_{i, t+1} \simeq r_{i, t+1}^{e}+\pi_{i, t+1}^{e}-\pi_{i, t+1} .
$$

Here, and in the sequel, we use a superscript " $e$ " as short-hand notation for $\mathrm{E}_{t}[\cdot]$. Further, $r_{i, t+1}^{e}+\pi_{i, t+1}^{e}$ is the nominal interest rate, which contains a component to compensate investors for the expected inflation incurred over the lifetime of the debt. We assume that

\footnotetext{
${ }^{6}$ In principle, we could set up a welfare function with each generation's utility as input. The relative weights attached to each generation's utility determine the government's degree of patience. However, to obtain simple, intuitive solutions, we propose an ad-hoc specification that captures in a simple way the trade-off that the government faces between raising taxes and issuing public debt.

${ }^{7}$ One would expect governments to discount the future at a higher rate when preferences of political parties differ more or when the government has a higher chance of losing office. In both cases, there is a stronger incentive to spend more now, because any remaining resources might be spent by another government with potentially different preferences. Cukierman et al. (1992) in their model derive the government's "effective" discount rate as an explicit function of the political factors mentioned here.
} 
international trade takes place without any barriers and that each individual, wherever she resides, consumes the same good or bundle of goods. The nominal exchange rate will then adjust perfectly and instantaneously to compensate for differences in inflation rates, thereby preventing arbitrage in goods trade. In particular, the nominal exchange rate moves to offset unexpected movements in relative inflation rates caused by the $\varepsilon$-shocks. As a result, the real return on a given country's debt is the same for any investor, no matter in which country she is residing.

While the inflation expectation $\pi_{i, t+1}^{e}$ is on average the correct prediction for the inflation rate, actual inflation generally differs from its expectation because of its stochastic link with the money growth rate. In this model, inflation uncertainty is the only source of uncertainty in the returns on public debt. In reality, uncertainty in public debt returns can be caused by other factors as well, such as occasional default or fluctuations in (the perception of) default risk. ${ }^{8}$ We abstract from these other sources of randomness in the debt returns, because they would complicate the formal analysis, while distracting the attention from the main results discussed below. Whatever the source of uncertainty, as we point out in the sequel, the key issue is how the correlations of the debt returns change with monetary unification. As we shall argue, the correlation of inflation rates will tend to increase among countries that form a monetary union, thereby contributing to higher correlations of the debt returns.

The primary objective of the central bank is to maintain price stability, that is, to stabilize the inflation rate around zero. However, the central bank also cares about the public debt that the government has to repay (possibly because of pressure from the fiscal authorities), and therefore has an incentive to create surprise inflation, thereby driving down the ex-post real debt return (6) on the nominal debt. Let us model this trade-off by assuming that the central bank minimizes the following loss-function:

$$
L_{i, t}^{\mathrm{cb}}=\mathrm{E}_{t}\left[\frac{1}{2}\left(\pi_{i, t+1}\right)^{2}+\lambda_{i} B_{i, t}\left(1+r_{i, t+1}\right)\right], \quad \text { with } \lambda_{i}>0 .
$$

One can interpret the parameter $\lambda_{i}$ as a measure of the central bank's dependence on the government. The higher is $\lambda_{i}$, the more dependent is the central bank, because it has a larger interest in softening the budgetary situation of the government, as measured by $B_{i, t}$.

Loss function (7) is very similar to the central banks' objective functions in Beetsma and Uhlig (1999), where the central bank is also concerned with the governments' finances. This allows for a similar channel through which higher inflation reduces the real debt servicing cost of the government. Such a channel is also present in Chari and Kehoe (2004). Higher (nominal) debt thus provides an incentive to relax monetary policy, thereby producing more inflation. The mechanism is analogous to that in Barro and Gordon (1983a, $1983 \mathrm{~b}$ ) and the large literature that followed their work. There, the objective of the central bank is formulated analogously to (7), but as a trade-off between stabilizing inflation and stimulating employment. The monetary authority then has an incentive to exploit nominal wage contracts (rather than the nominal debt contracts in this paper) in order to stimulate the economy.

When the countries $1, \ldots, N^{\mathrm{u}}$ form a monetary union, their central banks are replaced by a common central bank for the whole union. This common central bank determines $m_{t+1}^{\mathrm{u}}$, the

\footnotetext{
${ }^{8}$ For an empirical analysis of default risk premia on Euro-area public debt, see Bernoth et al. (2003); see also Arnold and Lemmen (2001).
} 
common nominal money growth rate in each country of the union. This, in turn, determines $\pi_{t+1}^{\mathrm{u}}$, the common inflation rate throughout the union. The relation between $m_{t+1}^{\mathrm{u}}$ and $\pi_{t+1}^{\mathrm{u}}$ is as in (5), where the stochastic shocks are now perfectly correlated among the countries that participate in the monetary union, but are still independent otherwise. The other properties of the shocks (in particular, their variances) are unaffected. Although this may come as a rather strong assumption, it is a priori not clear how monetary unification affects the degree to which a central bank is able to control the inflation rate. Hence, to avoid complicating the analysis with too many changes at the same time, we assume that the variance of the shock that links the money growth rate with the inflation rate is not affected by monetary unification.

The assumption of perfectly correlated $\varepsilon$-shocks across the union members is made purely for expositional convenience. Our results would be completely identical if we dropped this assumption and focussed directly on the stochastic properties of the inflation rates. As we will see below, all that matters are the correlations of inflation before and after monetary unification, because this determines the correlations of the real debt returns. ${ }^{9}$ In the absence of trade barriers, national inflation rates will be perfectly correlated in a union, irrespective of the correlation in the $\varepsilon$-shocks of union members. Differences in these shocks would simply be offset by differences in the growth rates of national holdings of the unionwide currency. It is then the union-wide money growth rate that determines the common inflation rate.

The loss function of the common central bank now depends on the union-wide inflation rate $\pi_{t+1}^{\mathrm{u}}$ and on the average real public debt burden that the different governments in the member countries will have to repay: ${ }^{10}$

$$
L_{t}^{\mathrm{cb}, \mathrm{u}}=\frac{1}{2} \mathrm{E}_{t}\left(\pi_{t+1}^{\mathrm{u}}\right)^{2}+\lambda^{\mathrm{u}} \mathrm{E}_{t}\left[\frac{1}{N^{\mathrm{u}}} \sum_{i=1}^{N^{\mathrm{u}}} B_{i, t}\left(1+r_{i, t+1}\right)\right], \quad \text { with } \lambda^{\mathrm{u}}>0 .
$$

We observe that countries with a higher debt level exert more influence on the common central bank's decisions.

Equation (5) implies that higher money growth, and therefore also higher expected inflation, goes hand in hand with a higher variance of inflation. Furthermore, as inflation uncertainty is the only source of uncertainty in the real debt returns, the variance of the inflation rate $\pi_{i, t+1}$ immediately yields the variance of $r_{i, t+1}$ :

$$
\operatorname{Var}_{t}\left(r_{i, t+1}\right)=\operatorname{Var}_{t}\left(\pi_{i, t+1}\right)=m_{i, t+1}^{2} \sigma^{2},
$$

which for $i \in\left\{1, \ldots, N^{\mathrm{u}}\right\}$ thus equals $\left(m_{t+1}^{\mathrm{u}}\right)^{2} \sigma^{2}$ in the case of monetary unification. Given that inflation is perfectly correlated across countries if they both participate in the monetary

\footnotetext{
${ }^{9}$ Note that nominal bond yields in the various member countries of EMU (except for Greece) have become virtually identical since 1998 (see European Commission 2002, p. 157). So the only remaining source of cross-country differences in real bond returns are cross-country differences in inflation rates.

${ }^{10}$ While the European Central Bank (ECB) is supposed to be completely independent from governments according to the Maastricht Treaty, in reality, there are many ways in which politicians can exert some influence on the ECB's policies. One possibility is through the appointment of the national Euro-area central bank presidents or the members of the ECB's Executive Board. These two groups together form the Governing Council which decides on the monetary policy stance in the Euro-area. Also, policymakers have repeatedly made public calls on the ECB to relax its policy stance. Overall, the assumption that $\lambda^{\mathrm{u}}>0$ seems to be a realistic one in the case of the ECB.
} 
union but independent across countries otherwise, we have the following expressions for the covariances between the real debt returns:

$$
\operatorname{Cov}_{t}\left(r_{i, t+1}, r_{j, t+1}\right)=\operatorname{Cov}_{t}\left(\pi_{i, t+1}, \pi_{j, t+1}\right)=\left(m_{t+1}^{\mathrm{u}}\right)^{2} \sigma^{2},
$$

if $i$ and $j$ both participate in a monetary union,

$$
\operatorname{Cov}_{t}\left(r_{i, t+1}, r_{j, t+1}\right)=\operatorname{Cov}_{t}\left(\pi_{i, t+1}, \pi_{j, t+1}\right)=0, \quad \text { otherwise. }
$$

\subsubsection{Equilibrium conditions}

Equilibrium in the goods market requires that

$$
N Y+\left(1+r^{*}\right) I_{t-1}=C_{1, t}+I_{t}+C_{2, t}+G_{t}
$$

where $C_{1, t} \equiv \sum_{i=1}^{N} C_{1, t}^{i}$ is the aggregate consumption of all young agents in the world, $C_{2, t} \equiv \sum_{i=1}^{N} C_{2, t}^{i}$ is the aggregate consumption of all old agents, $G_{t} \equiv \sum_{i=1}^{N} G_{i, t}$ is aggregate government consumption and $I_{t} \equiv \sum_{i=1}^{N}\left(Y-T_{i, t}-C_{1, t}^{i}\right) *\left(1-\sum_{j=1}^{N} \omega_{j, t}^{i}\right)$ is the aggregate investment in the risk-free rate technology. Hence, (11) says that aggregate production plus the gross return on the previous period's risk-free investment equals aggregate expenditure.

Equilibrium in the market for country $i$ 's public debt requires:

$$
B_{i, t}=\sum_{j=1}^{N}\left(Y-T_{j, t}-C_{1, t}^{j}\right) \omega_{i, t}^{j}, \quad \text { for all } i .
$$

\subsection{Solution of the model}

The timing within an arbitrary period $t$ is as follows. First, each government selects its public debt level. Simultaneously, conditional expectations $\mathrm{E}_{t}[\cdot]$ are formed and private sector agents take their investment decisions. In selecting its public debt, each government takes into account the private sector's demand schedule for its public debt, but takes as given the other governments' debt choices, as well as monetary policy. Next, the central bank of country $i$ chooses $m_{i, t+1}$, if $i$ does not participate in a monetary union, and the union central bank-if a union is formed-selects the common money growth rate $m_{t+1}^{\mathrm{u}}$. Finally, the shocks $\varepsilon_{i, t+1}$ materialize. This determines the realized inflation rate and the realized rate of return on the various countries' public debt. Hence, $\varepsilon_{i, t+1}$ is not included in the information set on which the conditional expectation $\mathrm{E}_{t}[\cdot]$ is based.

We first derive the representative agents' demand for public debt. Then, we derive the solutions to the problems faced by the governments and the central banks.

The first-order conditions of the representative young agent in country $i$ with respect to her decisions to hold country $j$ 's public debt and to invest in the risk-free technology, are:

$$
\begin{aligned}
1-\gamma C_{1, t}^{i} & =\frac{1}{1+\rho} \mathrm{E}_{t}\left[\left(1+r_{j, t+1}\right)\left(1-\gamma C_{2, t+1}^{i}\right)\right], \quad \text { for all } j, \\
C_{1, t}^{i} & =C_{2, t+1}^{i, e} .
\end{aligned}
$$


Substitute the budget constraint (1) into (13) and work out the argument of the expectations operator. One then finds:

$$
\begin{aligned}
1-\gamma C_{1, t}^{i}= & \frac{1}{1+\rho}\left(1+r_{j, t+1}^{e}\right)\left(1-\gamma C_{2, t+1}^{i, e}\right)-\frac{\gamma\left(Y-T_{i, t}-C_{1, t}^{i}\right)}{1+\rho} \\
& \times\left[\omega_{j, t}^{i} \operatorname{Var}_{t}\left(r_{j, t+1}\right)+\sum_{k=1, k \neq j}^{N} \omega_{k, t}^{i} \operatorname{Cov}_{t}\left(r_{j, t+1}, r_{k, t+1}\right)\right], \quad \text { for all } j .
\end{aligned}
$$

Aggregating across the representative agents of the different countries, taking into account the equilibrium conditions (12) and using the assumption that $r^{*}=\rho$, we obtain the following "mean-variance"-expression for the demand for country $i$ 's debt as a function of its expected real interest rate:

$$
\begin{aligned}
& r_{i, t+1}^{e}=r^{*}+\mu_{t}\left[B_{i, t} \operatorname{Var}_{t}\left(r_{i, t+1}\right)+\sum_{k=1, k \neq i}^{N} B_{k, t} \operatorname{Cov}_{t}\left(r_{i, t+1}, r_{k, t+1}\right)\right], \\
& \quad \text { with } \mu_{t}=\frac{\gamma}{N\left(1-\gamma \bar{C}_{1, t}\right)} .
\end{aligned}
$$

Here, $\bar{C}_{1, t}=C_{1, t} / N$ is the average consumption of the representative agents of the young generation across the different countries, so that $1-\gamma \bar{C}_{1, t}$ is the average marginal utility of consumption across agents.

Equation (15) shows that the expected return on country $i$ 's public debt, $r_{i, t+1}^{e}$, contains a risk premium above the risk-free rate $r^{*}$. The higher the amount of outstanding public debt $B_{i, t}$, and the higher the variance of its rate of return and the covariances of its rate of return with those on other countries' public debt, the higher the risk premium.

The problem of government $i$ amounts to the minimization of its loss function (4), subject to its budget constraint (3) and expression (15), taking the public debt of the other countries and monetary policy (and, thus, the (co)variances of the returns) as given. This yields the following expression for the supply of country $i$ 's debt as a function of its expected real interest rate:

$$
r_{i, t+1}^{e}=\beta_{i}-\mu_{t} B_{i, t} \operatorname{Var}_{t}\left(r_{i, t+1}\right) .
$$

The intuition for this expression is as follows. Government $i$ issues debt until the real interest rate that it expects to pay on its public debt equals its myopia $\beta_{i}$ minus a term that takes into account that a marginal increase of its indebtedness drives up the interest rate and, therefore, makes all of its outstanding debt more expensive. In the following, we shall confine the analysis to the case of $\beta_{i}>r_{i, t+1}^{e}$ (such that $B_{i, t}>0$ ) for all countries $i$.

We shall now consider the central banks' optimization problem. To this end, we shall distinguish the situation before and after monetary unification.

\subsubsection{Solution without a monetary union}

In the absence of a monetary union each country has its own central bank. The problem of the central bank of country $i$ is then to choose the money growth rate $m_{i, t+1}$ such that it minimizes its loss function (7), subject to (5) and taking the country's public debt level $B_{i, t}$ and the expected values $r_{i, t+1}^{e}$ and $\pi_{i, t}^{e}$ as given. This leads to

$$
m_{i, t+1}=\pi_{i, t+1}^{e}=\frac{\lambda_{i} B_{i, t}}{1+\sigma^{2}} .
$$


Hence, the money growth rate is increasing in the amount of debt and the degree of central bank dependence, $\lambda_{i}$.

From (9) and (10) we then obtain the second moments of the debt returns:

$$
\begin{aligned}
& \operatorname{Var}_{t}\left(r_{i, t+1}\right)=\left(\frac{\lambda_{i} B_{i, t}}{1+\sigma^{2}}\right)^{2} \sigma^{2} \equiv \tilde{\sigma}_{i}^{2}, \\
& \operatorname{Cov}_{t}\left(r_{i, t+1}, r_{j, t+1}\right)=0, \quad \text { for all } j \neq i .
\end{aligned}
$$

Substitute these expressions into (15-16), equate the resulting right-hand sides and solve to give

$$
B_{i, t}=\frac{\beta_{i}-r^{*}}{2 \mu_{t} \tilde{\sigma}_{i}^{2}} .
$$

After substituting (18) into (20) and solving, we find

$$
B_{i, t}^{\mathrm{nu}}=\left[\frac{\beta_{i}-r^{*}}{2 \mu_{t}^{\mathrm{nu}} \lambda_{i}^{2}}\left(\frac{1+\sigma^{2}}{\sigma}\right)^{2}\right]^{\frac{1}{3}}
$$

where the superscript "nu" refers to the case of "no union". For future use, we derive the public debt level of country $i \in\left\{1, \ldots, N^{\mathrm{u}}\right\}$ relative to the average public debt for this group of countries:

$$
b_{i, t}^{\mathrm{nu}} \equiv \frac{B_{i, t}^{\mathrm{nu}}}{\bar{B}_{t}^{\mathrm{nu}}}=\frac{\left[\left(\beta_{i}-r^{*}\right) / \lambda_{i}^{2}\right]^{\frac{1}{3}}}{\frac{1}{N^{\mathrm{u}}} \sum_{j=1}^{N^{\mathrm{u}}}\left[\left(\beta_{j}-r^{*}\right) / \lambda_{j}^{2}\right]^{\frac{1}{3}}}
$$

where $b_{i, t}^{\text {nu }}$ denotes the relative public debt level and $\bar{B}_{t}^{\text {nu }}$ the average debt level. Finally, the equilibrium expected real debt return follows upon combining (16) and (20):

$$
r_{i, t+1}^{e, \mathrm{nu}}=\frac{1}{2}\left(\beta_{i}+r^{*}\right)
$$

Equations (21-23) can be interpreted as follows. First recall the role of government $i$ 's myopia parameter $i$ : the higher $\beta_{i}$, the less weight government $i$ attaches to its public debt $B_{i, t}$ in its loss function (4), and the more public debt it supplies for a given expected rate of return according to the debt supply equation (16). But according to the debt demand equation (15), the representative agents of the different countries are only willing to hold more of country $i$ 's public debt if they receive a higher risk premium as a compensation for their greater exposure to shocks in country $i$ 's inflation rate. As a result, a higher value of $\beta_{i}$ increases not only the equilibrium value of country $i$ 's public debt $B_{i, t}^{\text {nu }}$ according to (21), but also the equilibrium value of the expected real interest rate $r_{i, t+1}^{e, \text { nu }}$ according to (23).

Let us now consider the role of the dependence parameter $\lambda_{i}$ of country $i$ 's central bank. The higher $\lambda_{i}$, the more the central bank worries about country $i$ 's public debt according to its loss function (7), and the more it is tempted-given inflation expectations-to create surprise inflation in order to decrease the real rate of return on government $i$ 's public debt and relieve its debt burden. This, however, leads to a stronger inflation bias, and-in a longrun rational expectations equilibrium - to faster money growth, as described by (17). But as faster money growth goes hand in hand with a larger inflation variance according to (9), the variance of the real interest rate on country $i$ 's public debt, $\operatorname{Var}_{t}\left(r_{i, t+1}\right)$, increases as well. As a result, the representative agents reduce their demand for country $i$ 's public debt according to the debt demand equation (15), while government $i$ reduces its supply of public 
debt according to the debt supply equation (16). In a long run equilibrium, a higher value of $\lambda_{i}$ therefore decreases country $i$ 's public debt $B_{i, t}^{\text {nu }}$, while it leaves the expected real rate of return $r_{i, t+1}^{e, \text { nu }}$ unaffected, as is apparent from (21) and (23). ${ }^{11}$

Finally, note from (22) that country $i$ 's share of public debt in the total public debt of the different countries $\left(b_{i, t}^{\text {nu }}\right)$ is higher the more myopic country $i$ 's government is compared with the other governments (i.e. the higher $\beta_{i}$ is compared to the values of $\beta$ in the other countries), and is lower the more country $i$ 's central bank worries about public debt compared with the other central banks (i.e. the higher $\lambda_{i}$ is compared to the values of $\lambda$ in the other countries).

Before moving on, it is worthwhile to point out that the model tries to capture the interaction between fiscal and monetary policy in the long run. ${ }^{12}$ More specifically, the assumption that higher public debt leads to a more relaxed monetary policy, is an assumption which holds in the long run, and for which there exists substantial evidence (for example, see Catão and Terrones 2005, who confirm this relation for advanced moderate-inflation economies, although it is stronger for high-inflation and/or less-developed countries). Note that the model presented here ignores another mechanism through which public debt may affect monetary policy in reality. A central bank that is confronted with a myopic government that runs up a large public debt, may want to increase the short-run interest rate and thereby tighten monetary policy in order to discipline the government. ${ }^{13}$ However, one would expect this mechanism to be only present in the short run. As time goes on, interest differentials with the rest of the world trigger capital flows and exchange rate adjustments. Eventually, the economy must move back to a long run equilibrium where the risk-free real interest rate is at the same level as abroad, and where the real rate of return on public debt only differs from the returns abroad to the extent that the risk characteristics of the underlying assets are different—as described in this paper.

\subsubsection{Solution with a monetary union}

Let us now consider the case where the countries $1, \ldots, N^{\mathrm{u}}$ form a monetary union. The problem of the common central bank is to choose the union-wide money growth rate $m_{t+1}^{\mathrm{u}}$ such that its loss function (8) is minimized subject to (5), taking as given all debt levels as well as the expected values $r_{i, t+1}^{e}$ and $\pi_{t+1}^{e, \mathrm{u}}$. This leads to:

$$
m_{i, t+1}=m_{t+1}^{\mathrm{u}}=\pi_{i, t+1}^{e}=\pi_{t+1}^{e, \mathrm{u}}=\frac{\lambda^{\mathrm{u}} \bar{B}_{t}^{\mathrm{u}}}{1+\sigma^{2}}
$$

for all countries $i$ that participate in the union,

\footnotetext{
${ }^{11}$ The fact that a higher inflation variance, and therefore also a higher value of $\operatorname{Var}_{t}\left(r_{i, t+1}\right)$, does not affect the expected real rate of return $r_{i, t+1}^{e, \text { nu }}$, is the result of the quadratic specification of the utility function and the linear-quadratic specifications of the loss functions of the central bank and the government. However, one expects the main intuition to survive with other specifications as well: generally, for a given expected rate of return, a higher return variance will reduce both the demand and the supply of debt. These effects work in opposite directions, so that the change in the equilibrium rate of return may be relatively small. This underlines the importance of explicitly modelling not only the demand for debt, but also its supply.

${ }^{12}$ The importance of looking at the long-term consequences of fiscal deficits for monetary policy was emphasized long ago by Sargent and Wallace (1981).

${ }^{13}$ Actually, Berger and Schneider (2000) report evidence that the German Bundesbank, which is often seen as a role model for central bank independence, had a tendency to yield to conflicts with the government (while taking an anti-inflationary stance otherwise). They define a conflict as a situation when monetary and fiscal policy are not compatible, because one is expansionary and the other is contractionary.
} 
where $\bar{B}_{t}^{\mathrm{u}}=\frac{1}{N^{\mathrm{u}}} \sum_{i=1}^{N^{\mathrm{u}}} B_{i, t}^{\mathrm{u}}$ is the average debt level in the union's member countries. The second moments of the debt returns then follow from $(9,10)$ :

$$
\begin{aligned}
& \operatorname{Var}_{t}\left(r_{i, t+1}\right)=\left(\frac{\lambda^{\mathrm{u}} \bar{B}_{t}^{\mathrm{u}}}{1+\sigma^{2}}\right)^{2} \sigma^{2} \equiv \hat{\sigma}^{2}, \quad \text { for all countries } i \text { that participate in the union, } \\
& \operatorname{Cov}_{t}\left(r_{i, t+1}, r_{j, t+1}\right)= \begin{cases}\hat{\sigma}^{2}, & \text { if countries } i \text { and } j \text { both participate in the union, } \\
0, & \text { otherwise. }\end{cases}
\end{aligned}
$$

Hence, we observe that countries with relatively high debt have a relatively large effect on money growth and the variance of the (common) ex-post real interest rate. If we substitute the above expressions into (15) and (16), we obtain, respectively,

$$
\begin{aligned}
& r_{i, t+1}^{e}=r_{t+1}^{e}=r^{*}+N^{\mathrm{u}} \mu_{t}^{\mathrm{u}} \bar{B}_{t}^{\mathrm{u}} \hat{\sigma}^{2}, \\
& r_{i, t+1}^{e}=\beta_{i}-\mu_{t}^{\mathrm{u}} B_{i t}^{\mathrm{u}} \hat{\sigma}^{2}
\end{aligned}
$$

where the superscript " $\mathrm{u}$ " in $\mu_{t}^{\mathrm{u}}$ and $B_{i t}^{\mathrm{u}}$ refers to the case of a monetary union. Take the union average of (27):

$$
r_{t+1}^{e}=\bar{\beta}^{\mathrm{u}}-\mu_{t}^{\mathrm{u}} \bar{B}_{t}^{\mathrm{u}} \hat{\sigma}^{2}
$$

where $\bar{\beta}^{\mathrm{u}}=\frac{1}{N^{\mathrm{u}}} \sum_{i=1}^{N^{\mathrm{u}}} \beta_{i}$ is the average value of $\beta_{i}$ across the union members. Combining (28) with (26) yields

$$
\bar{B}_{t}^{\mathrm{u}}=\frac{1}{\mu_{t}^{\mathrm{u}} \hat{\sigma}^{2}} \frac{\bar{\beta}^{\mathrm{u}}-r^{*}}{1+N^{\mathrm{u}}} .
$$

Substitute (24) into this expression and solve to obtain

$$
\bar{B}_{t}^{\mathrm{u}}=\left[\frac{\bar{\beta}^{\mathrm{u}}-r^{*}}{\left(1+N^{\mathrm{u}}\right) \mu_{t}^{\mathrm{u}}\left(\lambda^{\mathrm{u}}\right)^{2}}\left(\frac{1+\sigma^{2}}{\sigma}\right)^{2}\right]^{\frac{1}{3}} .
$$

For future use, we also derive the relative debt level:

$$
b_{i, t}^{\mathrm{u}} \equiv \frac{B_{i, t}^{\mathrm{u}}}{\bar{B}_{t}^{\mathrm{u}}}=1+\frac{\beta_{i}-\bar{\beta}^{\mathrm{u}}}{\bar{B}_{t}^{\mathrm{u}} \mu_{t}^{\mathrm{u}} \hat{\sigma}^{2}}=1+\left(1+N^{\mathrm{u}}\right) \frac{\beta_{i}-\bar{\beta}^{\mathrm{u}}}{\bar{\beta}^{\mathrm{u}}-r^{*}},
$$

which we obtain by combining (26-28). Finally, the equilibrium expected real debt return, which is the same for all union members, follows upon combining $(26,28)$ :

$$
r_{t+1}^{e, \mathrm{u}}=\frac{N^{\mathrm{u}}}{1+N^{\mathrm{u}}} \bar{\beta}^{\mathrm{u}}+\frac{1}{1+N^{\mathrm{u}}} r^{*}
$$

The expected debt returns and the public debt levels of the countries not in the union are still given by (23) and (21), respectively, but with $\mu_{t}^{\mathrm{nu}}$ replaced by $\mu_{t}^{\mathrm{u}}$.

\section{The effect of a monetary union on debt returns and public debt}

In this section we analyze how monetary unification affects the relative debt levels and the returns on the public debt of the union's members. 


\subsection{The effect on expected real returns}

Let us first consider the expected real debt returns. In the derivation of (23) and (31) the variance of the real return $\left(\tilde{\sigma}^{2}\right.$, respectively $\left.\hat{\sigma}^{2}\right)$ drops out and, thus, in equilibrium does not affect the expected real return. The reason for this is as follows. According to (15), the higher the variance $\operatorname{Var}_{t}\left(r_{i, t+1}\right)$, the less public debt investors are willing to hold in their portfolio for a given expected rate of return. However, according to (16), the higher $\operatorname{Var}_{t}\left(r_{i, t+1}\right)$, the less public debt the government will want to supply for a given expected rate of return. As a result, any change in the demand for debt due to a change in $\operatorname{Var}_{t}\left(r_{i, t+1}\right)$ will be accompanied by a change in the supply of debt of equal magnitude. This implies that in equilibrium, a change in $\operatorname{Var}_{t}\left(r_{i, t+1}\right)$ only affects the level of the public debt, but not its expected rate of return. This leads us to Proposition 1, which follows immediately from the preceding discussion.

Proposition 1 In equilibrium, uncertainty about the inflation rate does not affect the expected real debt returns. Consequently, whether inflation becomes more or less predictable when countries form a monetary union, does not matter for the expected real debt returns.

However, when countries form a monetary union, the returns on their public debt become perfectly correlated with each other. As a result, holding public debt of these countries increases the risk of the investors' overall portfolio, even when the variance of the debt returns does not change. Individuals will therefore demand a higher risk premium, which drives up the average expected rate of return. This yields Proposition 2.

Proposition 2 (a) The average expected real return on the public debt of the potential union members increases as a result of monetary unification. (b) Given that countries form a monetary union, the average expected real return on their public debt is increasing in the union size.

Proof (a) The average expected real rate of return on the public debt of countries $1, \ldots, N^{\mathrm{u}}$ before they form a monetary union follows from (23):

$$
\frac{1}{N^{\mathrm{u}}} \sum_{i=1}^{N^{\mathrm{u}}} r_{i, t+1}^{e, \mathrm{nu}}=\frac{1}{2}\left(\bar{\beta}^{\mathrm{u}}+r^{*}\right) .
$$

Equation (31) immediately yields the (average) expected real rate of return $r_{t+1}^{e, \mathrm{u}}$ when the countries do form a monetary union. As we assume throughout the analysis that $B_{i, t}>0$ for all countries $i$, it follows from (29) that $\bar{\beta}^{\mathrm{u}}>r^{*}$. This implies that $\frac{N^{\mathrm{u}}}{1+N^{\mathrm{u}}} \bar{\beta}^{\mathrm{u}}+\frac{1}{1+N^{\mathrm{u}}} r^{*}>$ $\frac{1}{2}\left(\bar{\beta}^{\mathrm{u}}+r^{*}\right)$, so that $r_{t+1}^{e, \mathrm{u}}>\frac{1}{N^{\mathrm{u}}} \sum_{i=1}^{N^{\mathrm{u}}} r_{i, t+1}^{e, \mathrm{nu}}$.

(b) Immediate from (31) and the fact that $\bar{\beta}^{\mathrm{u}}>r^{*}$.

While the average expected real return increases as a result of monetary unification, some countries may actually experience a fall in the expected real return on their debt, as a result of the fact that the expected returns on the participants' debt have converged to the same level. This will be the case for countries with a government that is sufficiently myopic relative to the other governments. All other governments will face an increase in the expected cost of issuing public debt.

To see the intuition for part (b) of Proposition 2, observe that an increase in the number of union members means that a larger amount of perfectly substitutable debt is issued. Hence, 


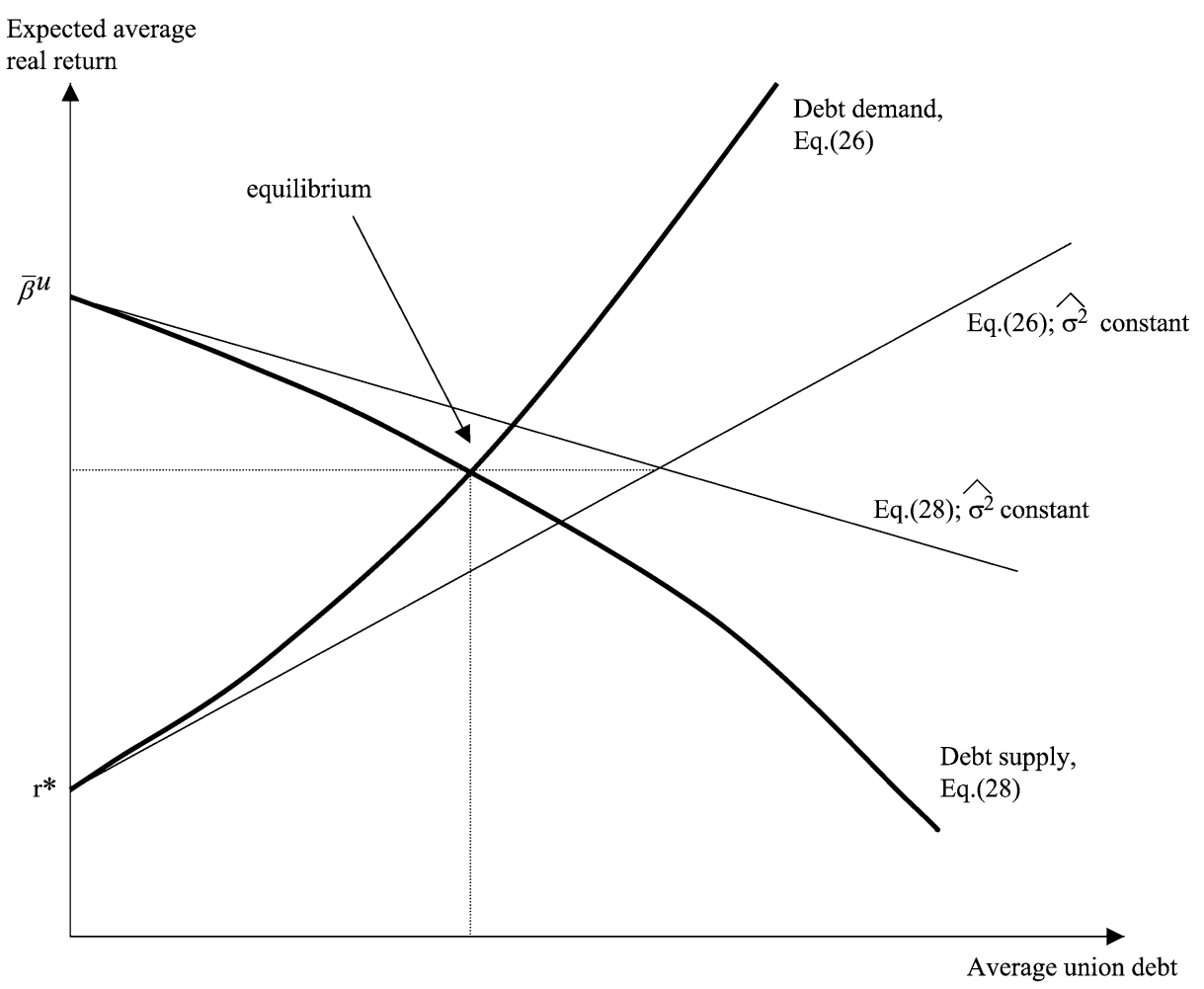

Fig. 1

for investors to be willing to buy this debt, the required expected return must be higher for any given level of $\bar{B}_{t}^{\mathrm{u}}$. This is captured by the term $N^{\mathrm{u}}$ in (26). In addition, the return variance, $\hat{\sigma}^{2}$, rises because of the increase in $\bar{B}_{t}^{\mathrm{u}}$. This further raises the required expected return for any given level of $\bar{B}_{t}^{\mathrm{u}}$. However, in equilibrium, this effect is offset by the fall in the supply of debt resulting from the higher return variance-see (28). Figure 1 depicts (26) and (28) as functions of $\bar{B}_{t}^{\mathrm{u}}$. An increase in $N^{\mathrm{u}}$ means that (26) becomes steeper and, hence, the equilibrium expected return rises.

\subsection{The effect on public debt}

Now, we further analyze the outcomes for public debt. Equation (21) shows that $B_{i, t}^{\text {nu }}$ depends on $\mu_{t}^{\mathrm{nu}}$. Similarly, $B_{i, t}^{\mathrm{u}}$ depends on $\mu_{t}^{\mathrm{u}}$. In turn, the values of $\mu_{t}^{\mathrm{nu}}$ and $\mu_{t}^{\mathrm{u}}$ are functions of the consumption of young agents without and with a monetary union, respectively, while consumption itself is determined jointly with the public debt levels. Unfortunately, there does not seem to exist a closed-form solution for consumption and the public debt levels. This prevents us from formally comparing the public debt levels before and after monetary unification.

However, we can circumvent this problem by looking at relative debt levels. These also seem politically more relevant, as it is difficult for a high-debt government to blame other governments for their indebtedness. Relative debt levels can become a much bigger source of tension in a monetary union, because they may lead to differences in the potential externalities that countries exert on each other. Here, the relevant externality is the 
effect of a country's debt on another country's expected real debt return. Equation (15) shows that the direct effect of country $j$ 's debt on country $i$ 's required real debt return is $\mu_{t} B_{j, t} \operatorname{Cov}_{t}\left(r_{i, t+1}, r_{j, t+1}\right)$. While in the absence of monetary unification, this direct effect is zero because $\operatorname{Cov}_{t}\left(r_{i, t+1}, r_{j, t+1}\right)=0$, the effect is positive when the two countries participate in a union. The relative size of this effect that the two countries exert on each other is the inverse of the ratio of their debt levels, $B_{j, t} / B_{i, t}$. The increased importance of the externality just described may help to explain why European countries have become more concerned about each other's fiscal discipline since EMU became a realistic prospect.

We are now ready to present Proposition 3.

Proposition 3 (a) If country i's government $\left(i=1, \ldots, N^{\mathrm{u}}\right)$ before monetary unification is sufficiently myopic compared to the governments of the other prospective members, then $i$ 's relative public debt level will increase after unification. (b) For countries that already form a union, the relative public debt level is increasing (decreasing) in the union size $N^{\mathrm{u}}$ if $\beta_{i}>\bar{\beta}^{\mathrm{u}}\left(\beta_{i}<\bar{\beta}^{\mathrm{u}}\right)$.

Proof (a) From $(22,30)$ it follows that the relative public debt level of country $i$ increases after monetary unification if and only if

$$
1+\left(1+N^{\mathrm{u}}\right) \frac{\beta_{i}-\bar{\beta}^{\mathrm{u}}}{\bar{\beta}^{\mathrm{u}}-r^{*}}>\frac{\left[\left(\beta_{i}-r^{*}\right) / \lambda_{i}^{2}\right]^{\frac{1}{3}}}{\frac{1}{N^{\mathrm{u}}} \sum_{j=1}^{N^{\mathrm{u}}}\left[\left(\beta_{j}-r^{*}\right) / \lambda_{j}^{2}\right]^{\frac{1}{3}}}=\frac{1}{\frac{1}{N^{\mathrm{u}}} \sum_{j=1}^{N^{\mathrm{u}}}\left[\left(\frac{\beta_{j}-r^{*}}{\beta_{i}-r^{*}}\right)\left(\frac{\lambda_{i}}{\lambda_{j}}\right)^{2}\right]^{\frac{1}{3}}} .
$$

As we assume throughout the analysis that $B_{i, t}>0$ for all countries $i,(30)$ implies that the left-hand side of the inequality above is always positive. If $\beta_{i}$ goes to $\infty$ (holding $\beta_{j}$ $(j \neq i)$ fixed), then the left-hand side of this inequality converges to $1+\left(1+N^{\mathrm{u}}\right)\left(N^{\mathrm{u}}-1\right)$, while the right-hand side converges to $N^{\mathrm{u}}$. Hence, the inequality will hold if government $i$ is sufficiently myopic relative to the other governments.

(b) Immediate from (30).

We can explain part (a) of Proposition 3 as follows. A country with a relatively myopic government will tend to have a relatively high public debt level for a given variance of real debt returns-see (21). Suppose first that this country has its own central bank. The relatively high public debt level will induce the central bank to try to create surprise inflation, which leads to a high money growth rate in equilibrium-see (17). This, in turn, causes high inflation uncertainty, and therefore also a high variance of the real debt returns. This adverse implication of issuing a relatively large amount of debt induces the government to limit its public debt somewhat. Suppose now that the country joins a monetary union, so that its central bank is replaced by a union-wide central bank. This union-wide central bank takes into account the public debt levels of all its member countries when deciding to what extent it will try to create inflation. It will, therefore, be less tempted to try to create high inflation and maintain a high money growth rate in response to the relatively high public debt level in an individual member country. However, if the money growth rate decreases in a country with a relatively high public debt level when it joins a monetary union, the inflation uncertainty, and therefore also the variance of real debt returns, will decrease as well. As a result, the mitigating feedback-effect on the public debt decision of the government will weaken, and the government will feel less restrained to issue debt. So, the indebtedness of a country with a relatively myopic government will increase after monetary unification compared to the average indebtedness in the union's member countries. 
Vice versa for a country with a government characterized by a relatively low degree of myopia.

Part (b) of Proposition 3 can be understood as follows. First, recall that the expected real debt return is increasing in the number of member countries of the monetary union (see Proposition 2(b)). Now, note from (27) that each member country will reduce its public debt by the same amount when the expected real debt return rises. Hence, when the union expands, countries with a relatively forward-looking government that already start with a relatively low debt level will decrease their public debt in absolute terms as much as countries with a relatively myopic government that start with a relatively high public debt level. As a result, when union expands, countries with a relatively myopic government will face an increase of their relative indebtedness compared with the average indebtedness in the union.

Now, we turn to the final result of this subsection, and establish:

Proposition 4 If the central bank of a country before monetary unification is sufficiently dependent relative to the central banks of the other prospective members, then the relative public debt level of the country increases after monetary unification (i.e., $b_{i, t}^{\mathrm{u}}>b_{i, t}^{\mathrm{nu}}$ ).

Proof Observe that the right-hand side of (32) converges to 0 when $\lambda_{i}$ goes to infinity (holding $\lambda_{j}(j \neq i)$ fixed). Hence, (32) holds if the central bank of country $i$ is sufficiently dependent relative to the other central banks.

The intuition behind Proposition 4 is as follows. For a given level of public debt, a country with a relatively dependent central bank (compared to the other prospective members of the monetary union) will have a relatively strong desire to create surprise inflation, and therefore in equilibrium a relatively high money growth rate. As explained above, the prospect of a high money growth rate has a mitigating effect on the amount of debt issued by the government. Hence, governments of countries with a relatively dependent central bank will have a relatively strong incentive to limit their public debt levels. However, in a monetary union, all governments face the same money growth rate. As a result, the relative public debt of countries that experience a relatively high money growth rate under monetary independence, will increase once they join the union.

\subsection{Extension}

Note that $\lambda^{\mathrm{u}}$, the common central bank's dependence parameter, can attain any positive value. As a result, $\lambda^{u}$ may or may not be related to the values of $\lambda_{i}$ in the loss functions of the individual central banks before the monetary union was formed. Our analysis therefore continues to hold even when we assume that countries that had relatively dependent central banks before the monetary unification, manage to lobby successfully for a relatively dependent common central bank in the monetary union. Similarly, $\lambda^{u}$ may or may not be related to the values of $\beta_{i}$ in the loss functions of the union countries' governments. Hence, the outcomes under a monetary union also remain valid if we assume that countries with relatively myopic governments manage to lobby successfully for a relatively dependent common central bank.

An interesting case is when $\lambda^{\mathrm{u}}$ is equal to a weighted average of the $\lambda_{i}$-values of the individual central banks before the monetary union, where the weights are given by the relative debt positions of the different governments (which in turn reflect relative degrees of myopia of the governments). This captures in a straightforward way the idea that countries 
with relatively large public debt levels lobby harder to influence monetary policy and can be formalized as $\lambda^{\mathrm{u}}=\frac{1}{N^{\mathrm{u}}} \sum_{i=1}^{N^{\mathrm{u}}} \lambda_{i} b_{i, t}^{\mathrm{u}}$, where $b_{i, t}^{\mathrm{u}}$ is country $i$ 's relative public debt level as defined before. In this case the common central bank's loss function boils down to the average of the loss functions of the individual central banks before the monetary union:

$$
\begin{aligned}
L_{t}^{\mathrm{cb}, \mathrm{u}} & =\frac{1}{2} E_{t}\left(\pi_{t+1}^{\mathrm{u}}\right)^{2}+\lambda^{\mathrm{u}} E_{t}\left[\frac{1}{N^{\mathrm{u}}} \sum_{i=1}^{N^{\mathrm{u}}} B_{i, t}\left(1+r_{i, t+1}\right)\right] \\
& =\frac{1}{2} E_{t}\left(\pi_{t+1}^{\mathrm{u}}\right)^{2}+\frac{1}{N^{\mathrm{u}}} \sum_{i=1}^{N^{\mathrm{u}}} \lambda_{i} b_{i, t}^{\mathrm{u}} E_{t}\left[\frac{1}{N^{\mathrm{u}}} \sum_{i=1}^{N^{\mathrm{u}}} B_{i, t}\left(1+r_{i, t+1}\right)\right],
\end{aligned}
$$

which in our setup simplifies to

$$
L_{t}^{\mathrm{cb}, \mathrm{u}}=\frac{1}{2} E_{t}\left(\pi_{t+1}^{\mathrm{u}}\right)^{2}+\frac{1}{N^{\mathrm{u}}} \sum_{i=1}^{N^{\mathrm{u}}} \lambda_{i} E_{t}\left[B_{i, t}\left(1+r_{i, t+1}\right)\right],
$$

because $r_{i, t+1}$ is equal across the union members.

An empirically plausible case occurs when government myopia combines with a relatively high degree of central bank dependence. That is, a high value of $\beta_{i}$ causes both $\lambda_{i}$ and $B_{i, t}$ to be high. Equations $(24,27)$ show that then, for given $r_{i, t+1}^{e}$, a higher value of $\beta_{i}$ has a direct positive effect on $B_{i, t}^{\mathrm{u}}$, but also a negative indirect effect on $B_{i, t}^{\mathrm{u}}$, because the higher value of $\lambda_{i}$ raises $\hat{\sigma}^{2}$ which, in turn, produces a negative effect on $B_{i, t}^{\mathrm{u}}$ for given $r_{i, t+1}^{e}$. In other words, the larger effect of an increase in its debt on the common central bank's policy implies that government $i$ moderates its fiscal profligacy.

\subsection{Euro-area data}

In principle, Propositions 1-4 provide empirical predictions that could be directly tested using data on inflation, real interest rates, (relative) debt levels and indices for central bank independence. However, there are at least two major obstacles to such tests. While our theory makes predictions about long-run relationships, the Euro has existed only for a limited number of years, which is less than a single business cycle for many countries. The movements in (relative) public debt, real interest rate and inflation observed so far are, therefore, dominated by short-run cyclical fluctuations in GDP. Using data from the OECD Economic Outlook, we have calculated the GDP-weighted average ex-post long-run real interest for the Euro-area (excluding Luxembourg and Greece), which falls from 3.40\% in 1998 (the year before the start of EMU) to $1.32 \%$ in 2005 . The corresponding figures for the rest of the OECD are $3.44 \%$ in 1998 and $1.49 \%$ in 2005 . Hence, the real interest rate has experienced a larger fall in the Euro area than in the rest of the OECD, which contrasts with what Proposition 2(a) predicts. However, it is well known that the Euro area has been lagging behind the world economy since the end of the nineties and that this has in particular been the case for its largest economies. While starting from mid-2003 the U.S. Fed has raised its target for the federal funds rate a large number of times, the ECB has been much slower raising its key main refinancing rate. With sticky price levels in the short run, the relative fall in the European real interest rate is not surprising.

The second major obstacle to testing our propositions is that our theory focuses on one specific aspect of monetary unification. In the case of EMU, however, many other aspects should be taken into account in order to interpret the data correctly. Especially the constraints on the member countries' fiscal policies imposed by the Stability and Growth Pact 
may be relevant. Furthermore, several other factors may affect the consequences of monetary unification for the risk characteristics of the public debt. For example, monetary unification may also affect liquidity premia (see Codogno et al. 2003) and reduce market segmentation, effects that are not modeled here, but that are likely to be of relevance in practice.

We have also computed relative debt levels between 1998 and 2005 as $b_{i, t}^{\mathrm{u}}=$ $B_{i, t} / \sum_{j}^{N^{\mathrm{u}}} B_{j, t}$, where $B_{i, t}$ is country $i$ 's public debt in period $t$ and $\sum_{j}^{N^{\mathrm{u}}} B_{j, t}$ is the total public debt in period $t$ in the entire Euro area (expressed in a common currency). ${ }^{14}$ The source of the data is again the OECD Economic Outlook. However, we see no clear pattern in the changes in relative debt. Of the countries that entered the Euro-area with more than $100 \%$ of GDP debt, Greece experienced an increase in relative debt, while Belgium and Italy saw their relative debt decline. The same obstacles for testing our theory on real interest rates remain present also for tests conducted on public debt.

\section{A simple transfer scheme to avoid the interest rate hike}

In the previous section, we showed that the average expected real debt return increases in our model when countries form a monetary union. In fact, this is due to a pecuniary externality that the governments of the individual countries do not internalize when they decide how much debt to supply. As (15) shows, the externality arises, because monetary unification raises the correlation of the returns on the public debt issued by the member countries. The question thus arises whether it is somehow possible to induce governments to internalize the interest rate externalities from the changes in public debt policies caused by monetary unification.

It turns out that the upward pressure on the expected real debt return can be offset with a simple transfer scheme that transfers resources to or from other countries when a country's public debt deviates from the average public debt level of the union members. Such a transfer scheme has some resemblance to the Stability and Growth Pact (SGP), which is also intended to discipline profligate governments. However, the SGP imposes sanctions for deficit/GDP ratios that exceed the $3 \%$ level, ${ }^{15}$ while the transfer scheme proposed here is effectively based on relative public debt levels. ${ }^{16}$ Hence, with the transfer scheme the budget constraint of the government of country $i$ becomes:

$$
B_{i, t}=G_{i, t}+B_{i, t-1}\left(1+r_{i, t}\right)+\tau\left(B_{i, t}-\bar{B}_{t}^{\mathrm{u}}\right)-T_{i, t}, \quad i=1, \ldots, N^{\mathrm{u}},
$$

where $\tau\left(B_{i, t}-\bar{B}_{t}^{\mathrm{u}}\right)$ is the transfer, with $\tau$ a constant which will be chosen in such a way that the average expected interest rate is restored to the pre-monetary union level. Observe that

\footnotetext{
${ }^{14}$ Note that the exchange rate fluctuations in 1998 have been minimal because the decision about the Euro conversion rates was made well in advance of the actual moment they were fixed. Hence, the computed relative debt levels in 1998 have hardly been affected by such fluctuations.

${ }^{15}$ For analyses of the SGP and closely related schemes, see e.g. Beetsma and Uhlig (1999), Beetsma and Bovenberg (2001), Debrun (2000), Dixit (2001) and Milesi-Ferretti (2004). More informal discussions of the Pact and its consequences can be found in Artis and Winkler (1998), Brunila et al. (2001) and Uhlig (2002).

${ }^{16}$ It is probably fair to say that relative deficit levels play a major role in the operation of the SGP. The reason is that the initiation of the so-called Excessive Deficit procedure and the ensuing sanctions are decided upon by qualified majority vote in the Council of Economics and Finance Ministers (ECOFIN) of the EU. Hence, fear of "retaliation" may prevent countries with high deficits to vote for imposing sanctions on other countries.
} 
the transfer scheme is budgetary neutral at the union level, because the sum of the transfers across all countries is zero.

The demand for country $i$ 's debt as a function of its expected real interest rate (15) remains unchanged. However, the supply of country $i$ 's debt as a function of its expected real interest rate is now found by minimizing the loss function (4), subject to $(15,33)$ :

$$
r_{i, t+1}^{e}=\beta_{i}-\mu_{t} B_{i, t} \operatorname{Var}_{t}\left(r_{i, t+1}\right)-\tau\left(\frac{N^{\mathrm{u}}-1}{N^{\mathrm{u}}}\right)\left(1+\beta_{i}\right) .
$$

By substituting $(24,25)$ into $(15,34)$ one can then solve for the expected real debt return in a monetary union with a transfer scheme:

$$
r_{t+1}^{e, \mathrm{u}}=\frac{N^{\mathrm{u}}}{1+N^{\mathrm{u}}} \bar{\beta}^{\mathrm{u}}+\frac{1}{1+N^{\mathrm{u}}} r^{*}-\left(\frac{N^{\mathrm{u}}-1}{N^{\mathrm{u}}+1}\right) \tau\left(1+\bar{\beta}^{\mathrm{u}}\right),
$$

which is, of course, constant across countries. The value of $\tau$ that restores the pre-unification expected average real interest rate for the region follows upon equating (35) to the union average of $(23), \frac{1}{2}\left(\bar{\beta}^{\mathrm{u}}+r^{*}\right)$. The solution is

$$
\tau^{\mathrm{u}}=\frac{1}{2}\left(\frac{\bar{\beta}^{\mathrm{u}}-r^{*}}{1+\bar{\beta}^{\mathrm{u}}}\right)>0 .
$$

Hence, the transfer scheme results in payments from member countries with a higherthan-average public debt to member countries with a lower-than-average public debt. The amount that a member country pays or receives is proportional to the difference between its own debt level and the average debt level across the union members. Note also that the proportionality factor is an increasing function of $\bar{\beta}^{\mathrm{u}}$, the average degree of myopia of the union governments.

Now, substitute (36) for $\tau, \frac{1}{2}\left(\bar{\beta}^{\mathrm{u}}+r^{*}\right)$ for $r_{i, t+1}^{e}$ and (24) for $\operatorname{Var}_{t}\left(r_{i, t+1}\right)$ into (34). Upon rewriting the resulting expression, we obtain

$$
B_{i, t}^{\mathrm{u}}=\frac{\left(1+\sigma^{2}\right)^{2}}{\mu_{t}^{\mathrm{u}}\left(\lambda^{\mathrm{u}} \bar{B}_{t}^{\mathrm{u}}\right)^{2} \sigma^{2}}\left\{\beta_{i}-r^{*}-\frac{1}{2}\left[1+\left(\frac{1+\beta_{i}}{1+\bar{\beta}^{\mathrm{u}}}\right)\left(\frac{N^{\mathrm{u}}-1}{N^{\mathrm{u}}}\right)\right]\left(\bar{\beta}^{\mathrm{u}}-r^{*}\right)\right\} .
$$

The final term in the curly brackets of this expression arises from the presence of the transfer scheme, which provides an incentive to government $i$ to reduce its public debt. With the use of (37), we compute the new average debt level in the union:

$$
\bar{B}_{t}^{\mathrm{u}}=\left[\frac{\bar{\beta}^{\mathrm{u}}-r^{*}}{2 N^{\mathrm{u}} \mu_{t}^{\mathrm{u}}\left(\lambda^{\mathrm{u}}\right)^{2}}\left(\frac{1+\sigma^{2}}{\sigma}\right)^{2}\right]^{\frac{1}{3}} .
$$

Holding $\mu_{t}^{\mathrm{u}}$ constant, the average debt level falls compared to the situation without the transfer scheme. This is not surprising, given that the transfer scheme makes it more costly for governments to issue debt.

The relative debt levels are now given by

$$
b_{i, t}^{\mathrm{u}} \equiv \frac{B_{i, t}^{\mathrm{u}}}{\bar{B}_{t}^{\mathrm{u}}}=1+2 N^{\mathrm{u}}\left(\frac{\beta_{i}-\bar{\beta}^{\mathrm{u}}}{\bar{\beta}^{\mathrm{u}}-r^{*}}\right)+\left(1-N^{\mathrm{u}}\right)\left(\frac{\beta_{i}-\bar{\beta}^{\mathrm{u}}}{1+\bar{\beta}^{\mathrm{u}}}\right) .
$$

Now, compare (38) with (30). It is easy to check that the transfer scheme implies a rise (fall) in the relative debt level iff $\beta_{i}>(<) \bar{\beta}^{\mathrm{u}}$. The fall in the average debt level induced by the 
transfer scheme "blows up" the relative debt levels, despite the fact that the scheme provides a more myopic government with a stronger incentive to reduce its debt-see (37). Hence, with the proposed scheme, the least disciplined governments issue an even larger share of the union's debt.

We can now summarize the results of this section in the following proposition.

Proposition 5 We have that (a) a linear transfer scheme which depends on the difference between the individual and average union debt is able to restore the pre-unification average expected debt return and (b) the dispersion in relative debt levels increases further with the introduction of this transfer scheme.

\section{Conclusion}

While the effects of monetary unification on real interest rates and (relative) public debt accumulation have to a large extent been ignored in the literature, in the preceding analysis we have demonstrated that this may be unjustified. The implications of unification for the real interest rate become important when the returns on the public debt are imperfectly correlated across countries. Monetary unification increases the substitutability of the public debt. As a result, our model predicts a rise in expected debt-servicing costs. In addition, the share of the union debt issued by relatively undisciplined governments increases. Similarly, the share of the union debt issued by a country initially characterized by a relatively dependent central bank rises. These effects of monetary unification on the spread of the relative debt levels may be a source of political tension and provide some governments with an incentive to put pressure on other governments to reduce their debt. This, in turn, may weaken the political sustainability of a monetary union. We have also explored the introduction of a transfer scheme that punishes increases of the national debt beyond the average debt level in the union. Such a scheme can indeed reduce the average expected real debt return to the pre-unification level. However, it further magnifies the spread in relative debt levels.

To keep the analysis as simple as possible we have assumed an exogenous degree of government myopia. However, in reality, such myopia will generally be determined by the political landscape and the way the electoral system works. For instance, governments that need to be formed by party coalitions (as is relatively likely under a system of proportional representation) tend to be characterized by internal ideological differences, and this ideological fragmentation may result in government deficits—-see Balassone and Giordano (1999) for a theoretical formalization and some empirical evidence for a sample of European countries. Volkerink and de Haan (2001) do not find evidence for this hypothesis, but argue that size fragmentation, which refers to the number of parties or spending ministers in government, produces higher deficits — an empirical result confirmed by Ricciuti (2004). Huber et al. (2003) stress the importance of power dispersion within coalition governments: coalition governments with equally strong partners run significantly higher deficits than coalitions with one dominating party. Furthermore, there exists a widespread belief that shorter expected tenure or a higher turnover rate of governments produces more myopic policies (an example might be Italy), even though formal testing by Ricciuti (2004) does not find clear evidence for this hypothesis.

A relevant extension of our set-up would therefore be to endogenize differences in government myopia by explicitly taking into account its sources. This would link differences in relative debt and cross-border interest rate externalities to the political systems and electoral 
processes in the union members. ${ }^{17}$ We could then even go one step further, and investigate whether it is in the interests of re-election-minded politicians to join a monetary union, given the effects of union membership on public debt and domestic interest rates. Indeed, politicians of large Euro-area member states have repeatedly expressed in public their concern about the "too high" level of the interest rate. Also, some of the contributors (e.g., Barrell and Minford) to the EMU study commissioned by the British Treasury (HM Treasury 2003) have pointed out the danger of increasing public debt in some Euro-area members and concomitant higher real interest rates. However, such an analysis would be beyond the scope of the present paper. Yet, we believe that our modeling strategy, where we take union membership and the different governments' degree of myopia as exogenously given, is an appropriate first step in analyzing the issues raised in this paper.

In addition to some of the public choice extensions discussed in the previous paragraphs, a number of other extensions might be worthwhile to pursue. A fully-fledged analysis of the implications of monetary unification for debt-servicing costs should also take into account how unification affects the liquidity of the public debt of individual countries. In particular, due to the reduction of formal and informal barriers to cross-border financial transactions, the size of the market for its public debt may expand when a country becomes part of a monetary union. This makes it easier for investors to adjust their public debt holdings. Hence, potential liquidity premia will shrink. Another extension allows for differences in inflation rates also after monetary unification. Even though unification is likely to increase the correlation of national inflation rates and thus of real debt returns, (short-run) differences in national inflation rates can persist for several reasons, such as cross-country differences in consumption bundles or the presence of non-tradables. While our results are unlikely to be qualitatively affected, such complications will surely have quantitative implications for the change in borrowing costs and relative debt levels after unification. A third extension is to enrich the stochastic structure of the model by introducing (time-varying) default risk. Even though default on public debt of EMU members seems a remote possibility at present, in the longer run it may not be excluded, especially if governments respond to increasing costs of population aging by issuing more debt. The crucial question is how monetary unification affects the correlation of default risks and thus the risk premium in the required debt returns.

Acknowledgements We thank two anonymous referees, the Editor-in-Chief, Lorenzo Bini-Smaghi, Matteo Governatori, Marco Hoeberichts, Andrew Hughes-Hallett, Frank de Jong, Ludger Schuknecht, seminar participants at the University of Amsterdam, the University of Cologne, De Nederlandsche Bank and the European University Institute, and participants of the CESifo-LBI conference "Sustainability of Public Debt," the INSEAD/CEPR conference "Political, Institutional and Economic Determinants of Fiscal Policy," the CEPII Workshop on Fiscal Discipline and the conference "Financial Markets, Business Cycles, and Growth" at Birkbeck College for helpful comments. The usual disclaimer applies.

\section{References}

Arnold, I., \& Lemmen, J. (2001). The vulnerability of banks to government default risk in the EMU. International Finance, 4, 101-125.

Artis, M., \& Winkler, B. (1998). The stability pact: safeguarding the credibility of the European Central Bank. National Institute Economic Review, 163, 87-98.

Baele, L., Ferrando, A., Hördahl, P., Krylova, E., \& Monnet, C. (2004). Measuring financial integration in the euro area. ECB occasional paper, No. 14.

\footnotetext{
${ }^{17}$ For an analysis of the political economy of public debt, see Persson and Tabellini (1999) and Drazen (2000), as well as the references therein.
} 
Balassone, F., \& Giordano, R. (1999). Budget deficits and coalition governments. Public Choice, 106, 327 349.

Barro, R. J., \& Gordon, D. B. (1983a). Rules, discretion and reputation in a model of monetary policy. Journal of Monetary Economics, 12, 101-121.

Barro, R. J., \& Gordon, D. B. (1983b). A positive theory of monetary policy in a natural rate model. Journal of Political Economy, 91, 589-610.

Beetsma, R., \& Bovenberg, A. L. (1998). Monetary union without fiscal coordination may discipline policymakers. Journal of International Economics, 45, 239-258.

Beetsma, R., \& Bovenberg, A. L. (1999). Does monetary unification lead to excessive debt accumulation? Journal of Public Economics, 74, 299-325.

Beetsma, R., \& Bovenberg, A. L. (2001). The optimality of a monetary union without a fiscal union. Journal of Money, Credit, and Banking, 33, 179-204.

Beetsma, R., \& Uhlig, H. (1999). An analysis of the stability and growth pact. Economic Journal, 109, 546571.

Berger, H., \& Schneider, F. (2000). The Bundesbank's reaction to policy conflicts. In J. de Haan (Ed.), Fifty years of Bundesbank: lessons for the ECB (pp. 43-66). London: Routledge.

Bernoth, K., Schuknecht, L., \& von Hagen, J. (2003). The determinants of the yield differential in the EU bond market. Mimeo, Center for European Integration Studies, Bonn University/European Central Bank.

Brunila, A., Buti, M., \& Franco, D. (Eds.). (2001). The stability and growth pact. New York: Palgrave.

Buiter, W. H., Corsetti, G., \& Roubini, N. (1993). Excessive deficits: sense and nonsense in the treaty of Maastricht. Economic Policy, 8, 57-100.

Calmfors, L. (2001). Unemployment, labor market reform and monetary union. Journal of Labor Economics, $19,265-289$.

Canzoneri, M. B., \& Diba, B. T. (1991). Fiscal deficits, financial integration, and a Central Bank for Europe. Journal of the Japanese and International Economies, 5, 381-403.

Capiello, L., Engle, R., \& Shephard, K. (2003). Asymmetric dynamics in the correlations of global equity and bond returns. ECB working paper, No. 204

Catão, L. A. V., \& Terrones, M. E. (2005). Fiscal deficits and inflation. Journal of Monetary Economics, 52, 529-554.

Chang, R. (1990). International coordination of fiscal deficits. Journal of Monetary Economics, 25, 347-366.

Chari, V., \& Kehoe, P. J. (2004). On the desirability of fiscal constraints in a monetary union. NBER discussion paper, No. 10232.

Codogno, L., Favero, C., \& Missale, A. (2003). Yield spreads on EMU government bonds. Economic Policy, $18,503-532$.

Cukierman, A., \& Lippi, F. (2001). Labour markets and Monetary Union: a strategic analysis. Economic Journal, 111, 541-565.

Cukierman, A., Edwards, S., \& Tabellini, G. (1992). Seignorage and political instability. American Economic Review, 82, 537-555.

Debrun, X. (2000). Fiscal rules in a monetary union: a short run analysis. Open Economies Review, 11, $323-358$.

De Grauwe, P., \& Polan, M. (2001). Increased capital mobility: a challenge for national macroeconomic policies. In H. Siebert (Ed.), The world's new financial landscape: challenges for economic policy. Berlin: Springer.

Dixit, A. (2001). Games of monetary and fiscal interactions in the EMU. European Economic Review, 45, 589-613.

Drazen, A. (2000). Political economy in macroeconomics. Princeton: Princeton University Press.

European Commission (2002). Bond market integration in the EU. European Economy 6, Directorate General for Economic and Financial Affairs, Brussels.

Ford, R., \& Laxton, D. (1999). World public debt and real interest rates. Oxford Review of Economic Policy, 15, 77-94.

HM Treasury (2003). Submissions on EMU from leading academics. London, www.hm-treasury.gov.uk.

Huber, G., Kocher, M., \& Sutter, M. (2003). Government strength, power dispersion in governments and budget deficits in OECD-countries. A voting power approach. Public Choice, 116, 333-350.

Illing, G. (1999). Nominal bonds and budgetary discipline in a currency union. Kredit und Kapital, 32, 1-23.

Leith, C., \& Wren-Lewis, S. (2000). Interactions between monetary and fiscal policy rules. Economic Journal, 110, C93-108.

Leith, C., \& Wren-Lewis, S. (2002). Interactions between monetary and fiscal policy under EMU. Mimeo, Universities of Glasgow and Exeter.

Milesi-Ferretti, G. M. (2004). Good, bad or ugly? On the effects of fiscal rules with creative accounting. Journal of Public Economics, 88, 377-394.

Missale, A. (1999). Public debt management. Oxford: Oxford University Press. 
Mundell, R. A. (1961). A theory of optimum currency areas. American Economic Review, 51, 657-665.

Neumeyer, P. A. (1998). Currencies and the allocation of risk: the welfare effects of a monetary union. American Economic Review, 88, 246-259.

Pagano, M., \& von Thadden, E.-L. (2004). The European bond markets under EMU. CEPR discussion paper, No. 4779 .

Persson, T., \& Tabellini, G. (1999). Political economics and macroeconomic policy. In J. B. Taylor, M. Woodford (Eds.), Handbook of macroeconomics, Vol. 1. Amsterdam: Elsevier.

Restoy, F. (1996). Interest rates and fiscal discipline in monetary unions. European Economic Review, 40, 1629-46.

Ricciuti, R. (2004). Political fragmentation and fiscal outcomes. Public Choice, 118, 365-388.

Sargent, T. J., \& Wallace, N. (1981). Some unpleasant monetarist arithmetic. Federal Reserve Bank of Minneapolis Quarterly Review, 5, 1-17.

Uhlig, H. (2002). One money, but many fiscal policies in Europe: what are the consequences? CEPR discussion paper, No. 3296.

Van Aarle, B., Bovenberg, A. L., \& Raith, M. (1997). Is there a tragedy of a Common Central Bank? A dynamic analysis. Journal of Economic Dynamics and Control, 21, 417-447.

Volkerink, B., \& de Haan, J. (2001). Fragmented government effects on fiscal policy. Public Choice, 109, 221-242. 